\title{
GOVERNMENT SIZE AND REGIONAL ECONOMIC GROWTH: ANOTHER LOOK
}

\author{
Bruce R. Domazlicky*
}

\begin{abstract}
A production function approach is used to explore the effect of government size on economic growth in the forty-eight contiguous states during the period 1977-89. Following Durden and Elledge, government employment is used as the measure of government size. The results indicate that the growth rate of gross state product (GSP) is not related to government size and the growth rate of per capita GSP is negatively related to government size. The conclusion is that there is little evidence of a positive effect of government size on regional economic growth.
\end{abstract}

\section{INTRODUCTION}

In a recent article in this Review, Durden and Elledge (1993) (hereafter DE) presented evidence to indicate that government employment has a positive and significant effect on the growth of gross state product. In addition, they found that state and local government employment had a larger impact on growth than did federal government employment, which was generally insignificant in their estimations.

This short note is an attempt to extend their analysis and to make some minor improvements in methodology. The extension is to use a cross-section, time-series approach as opposed to a cross-section approach for a single year. Since we are concerned with the effect of government size on regional growth, a model which includes a time series component would appear to be more appropriate than a cross-section model for a single year.

We make several changes in the methodology of DE. First, we use private gross state product to measure growth in the forty-eight continental states. Private gross state product (GSP) is determined by subtracting government output from total GSP. If total GSP is used, there arises the possibility of spurious correlation between a dependent (GSP) that includes government output and one of the independent variables, government employment. We use private gross state product to eliminate this possibility. Second, private employment is used as the measure of labor input rather than total employment. This would seem to be a required change if the dependent variable is private GSP. In addition, using private employment lessens the likelihood of multicollinearity problems with government

*Professor of Economics, Southeast Missouri State University. The author wishes to thank William L. Weber and anonymous referees for their useful comments. 
employment that might occur if total employment, which includes government employment, were used. Third, DE use gross state product (GSP), a measure of extensive growth, as their dependent variable. A review of the literature indicates that many researchers (Landau 1983, 1986; Ram 1986, and Barro 1991) use per capita GSP, a measure of intensive growth, for their dependent variable. Fourth, because a cross-section, time-series approach is used, it is possible to use the growth rate of (per capita) GSP as the dependent variable. This allows for a more direct estimate of the impact of government size on regional growth than is possible in a cross-section model.

Section II will present a brief discussion of the data and methodology used for the model. The empirical results are presented in section III, and section IV offers a brief conclusion.

\section{DATA AND METHODOLOGY}

Durden and Elledge provide a good discussion of the potential positive and negative effects of government on growth as well as a brief review of the literature. The interested reader is advised to reference their article for further information and sources.

Since there is no accepted theory with respect to the effect of government spending on economic growth, most researchers, including DE, use a production function approach. A measure of output (e.g., Gross Domestic Product) is regressed on measures of capital, labor, and human capital. A measure of government size (employment, spending, etc.) is then added to the production function to determine if it has an effect on the growth of output. The present study uses the production function approach. As indicated previously, the forty-eight continental states are selected to test the effect of government on regional growth. The time period chosen for study is 1977-1989. Given forty-eight states and thirteen years, there are 624 available observations. When the growth rate of GSP is used, the number of observations is reduced to 576 .

The dependent variable is private gross state product (millions of current dollars). Because of the absence of suitable regional price deflators, it is necessary to use current values for all monetary variables (GSP and CAP). Utilizing a production function approach, Gross State Product is a function of the amount of physical capital (CAP), human capital (EDUC) and labor (EMP) that is employed in a state. Since actual data on capital stock are not available, we follow the approach of Durden and Elledge and use capital charges (millions of current dollars; see Beemiller and Dunbar 1993) as a proxy for the level of capital stock in a state. Private employment is found by subtracting government employment (federal, 
state and local) from total employment. The human capital variable (EDUC) is measured by the percent of a state's population having completed sixteen or more years of school. Data on the percent of population with at least 16 years of education are available only for census years. For intercensal years, it was assumed that the percent increased in constant absolute increments each year. For example, if the population with at least 16 years of education increased by twenty percentage points between census years, then it was assumed that this variable increased by two percentage points in each intercensal year. This is admittedly an ad hoc approach, but no other suitable educational variables are available on an annual basis for states. It should be noted that the empirical results with respect to government size reported in the next section are not affected if this variable is excluded from the regressions. The census year figures were compiled from the County and City Data Book. ${ }^{1}$

Several variables could be employed to measure the size of government in a regional economy. One is to use total government spending, which includes transfer payments. Since private individuals ultimately make expenditure decisions for transfer payments, a government spending variable perhaps should not include such payments. A second possible variable would be to use government output as measured in the GSP accounts. A third possibility is to use government employment. This is the variable of choice for DE. It is likely that all three variables would be highly correlated, particularly the latter two. We follow DE and use government employment as our measure of government size. Three separate measures of government employment in a state are used in this study: total government employment (GOV), federal government employment (FED) and state and local government employment (SLG). In addition, the relative level of government employment (GOVR) is used in some equations. This variable is total government employment divided by total private employment. This allows a test for the existence of a nonlinear relationship between government size and growth of GSP (Grossman 1988). ${ }^{2}$

\section{EMPIRICAL RESULTS}

The use of pooled data introduces the possibility that the regression intercept may shift over time and across states. Therefore, a covariance model was used. This involves using dummy variables for each time period (minus one) and for each state (minus one). Therefore, a total of 59 dummy variables were added. An F-test is then performed to see if the addition of the dummy variables significantly reduces the error sum of squares. [See Pindyck and Rubinfeld (1991, pp. 224 226)]. In all cases, the F-test was significant, indicating that a covariance model 
should be used. Since the dummy variables do not have a useful economic interpretation, their values and significance levels are not reported in the tables that follow.

Three variables, employment (EMP), capital (CAP) and education (EDUC), are included in some form in all models. With the exception of EDUC in Table 1, the three variables are significant at the one percent level and have the expected signs (positive) in all equations. The estimates of the coefficients of the three variables exhibit remarkable stability across equations for a given model type (see Tables 1-4).

The extensive growth model that is closest to that of $\mathrm{DE}$ is presented in Table 1. The regression results are also very similar to DE. Equation (1) indicates that total government employment has a positive and significant effect on GSP.

TABLE 1

Extensive Growth Model

Dependent Variable: Gross State Product (GSP)

\begin{tabular}{lrrrr}
\hline \hline Variable & \multicolumn{1}{c}{$(1)$} & \multicolumn{1}{c}{$(2)$} & \multicolumn{1}{c}{$(3)$} & \multicolumn{1}{c}{$(4)$} \\
\hline CONSTANT & -22907 & -27914 & -9390 & -40442 \\
& $(.0048)$ & $(.0005)$ & $(.2523)$ & $(.0001)$ \\
EMP & .0067 & .0069 & .0160 & .0104 \\
& $(.0002)$ & $(.0001)$ & $(.0001)$ & $(.0001)$ \\
CAP & 3.029 & 3.021 & 2.951 & 2.953 \\
& $(.0001)$ & $(.0001)$ & $(.0001)$ & $(.0001)$ \\
EDUC & 448.65 & 589.32 & 191.21 & 697.87 \\
& $(.1418)$ & $(.0544)$ & $(.5534)$ & $(.0284)$ \\
GOV & .0818 & -- & -- & .0653 \\
& $(.0001)$ & & & $(.0001)$ \\
GOVR & -- & -- & -- & 88626.4 \\
& & & & $(.0009)$ \\
SLG & -- & .111 & -- & - \\
& & $(.0417)$ & & - \\
FED & -- & -- & -.038 & \\
& & & $(.1504)$ & \\
adj. $R^{2}$ & .998 & .998 & .998 & .998 \\
F & 4358 & 4561 & 4008 & 4368 \\
\hline
\end{tabular}

Figures in parentheses are significance levels of the t-test. $N=624$. 
But, similar to DE, state and local government employment is positive and significant, while federal government employment is negative and insignificant (equations (2) and (3)). In contrast to DE, equation (4) also indicates that GSP increases as the relative level of government employment increases in a state.

Table 2 presents the results of the intensive growth model. All variables (except EDUC and GOVR) are divided by population. (A "PC" prefix is used to indicate that a variable is in per capita terms.) In equations (1), (2), and (3), all measures of government size are negative and significant. Apparently, government size may positively affect extensive growth, but not intensive growth. However, in equation (4), while per capita government employment is still negative and significant, the relative level of government employment (GOVR) appears to have a positive (and significant) effect on per capita GSP.

TABLE 2

Intensive Growth Model

Dependent Variable: Per Capita GSP

\begin{tabular}{|c|c|c|c|c|}
\hline Variable & (1) & (2) & (3) & (4) \\
\hline CONSTANT & $\begin{array}{r}-.719 \\
(.0001)\end{array}$ & $\begin{array}{r}-1.003 \\
(.0001)\end{array}$ & $\begin{array}{r}-.737 \\
(.0001)\end{array}$ & $\begin{array}{r}-1.991 \\
(.0001)\end{array}$ \\
\hline PCEMP & $\begin{array}{r}.030 \\
(.0001)\end{array}$ & $\begin{array}{r}.032 \\
(.0001)\end{array}$ & $\begin{array}{r}.031 \\
(.0001)\end{array}$ & $\begin{array}{r}.062 \\
(.0001)\end{array}$ \\
\hline PCCAP & $\begin{array}{r}1.255 \\
(.0001)\end{array}$ & $\begin{array}{r}1.240 \\
(.0001)\end{array}$ & $\begin{array}{r}1.272 \\
(.0001)\end{array}$ & $\begin{array}{r}1.162 \\
(.0001)\end{array}$ \\
\hline EDUC & $\begin{array}{r}.035 \\
(.0001)\end{array}$ & $\begin{array}{r}.035 \\
(.0001)\end{array}$ & $\begin{array}{r}.032 \\
(.0001)\end{array}$ & $\begin{array}{r}.018 \\
(.0001)\end{array}$ \\
\hline PCGOV & $\begin{array}{r}-.044 \\
(.0001)\end{array}$ & - & - & $\begin{array}{r}-.183 \\
(.0001)\end{array}$ \\
\hline GOVR & -- & -- & -- & $\begin{array}{r}9.035 \\
(.0001)\end{array}$ \\
\hline PCFED & -- & $\begin{array}{r}-.067 \\
(.0012)\end{array}$ & -- & $\ldots$ \\
\hline PCSLG & -- & -- & $\begin{array}{r}-.043 \\
(.0031)\end{array}$ & -. \\
\hline $\operatorname{adj} . R^{2}$ & .977 & .977 & .977 & .979 \\
\hline $\mathbf{F}$ & 416.3 & 412.3 & 411.0 & 450.8 \\
\hline
\end{tabular}

Figures in parentheses are significance levels of the t-test. $N=624$. 
Tables 3 and 4 present essentially the same models as Tables 1 and 2, respectively, except for the use of the growth rates of the dependent and independent variables (denoted by a "G" suffix). In Table 3, the growth rate of total government employment is positive but insignificant (equation (1)). However, the growth rate of state and local government employment still appears to have a positive and significant impact on the growth of GSP, while the growth rate of federal employment is insignificant (equations (2) and (3)). When total government employment and its relative are included (equation (4)), neither is significant.

TABLE 3

Extensive Growth Rate Model

Dependent Variable: Growth Rate of GSP

\begin{tabular}{lrrrr}
\hline \hline Variable & \multicolumn{1}{c}{$(1)$} & \multicolumn{1}{c}{$(2)$} & \multicolumn{1}{c}{$(3)$} & \multicolumn{1}{c}{$(4)$} \\
\hline CONSTANT & -.034 & -.036 & -.033 & -.032 \\
& $(.0059)$ & $(.0031)$ & $(.0064)$ & $(.0086)$ \\
EMPG & 1.458 & 1.445 & 1.474 & 2.522 \\
& $(.0001)$ & $(.0001)$ & $(.0001)$ & $(.0012)$ \\
CAPG & .069 & .069 & .069 & .070 \\
& $(.0001)$ & $(.0001)$ & $(.0001)$ & $(.0001)$ \\
EDUCG & 2.777 & 2.797 & 2.804 & 2.782 \\
& $(.0001)$ & $(.0001)$ & $(.0001)$ & $(.0001)$ \\
GOVG & .091 & -- & -- & -.989 \\
& $(.2682)$ & & & $(.2105)$ \\
GOVRG & -- & -- & -- & 1.334 \\
& & & & $(.1693)$ \\
SLGG & -- & .177 & -- & - \\
& & $(.0147)$ & & - \\
FEDG & -- & -- & -.039 & - \\
& & & $(.2236)$ & \\
adj. $R^{2}$ & .815 & .817 & .815 & .815 \\
F & 41.8 & 42.3 & 41.9 & 41.3 \\
\hline
\end{tabular}

Figures in parentheses are significance levels of the $t$-test. $N=576$.

The intensive growth rate model in Table 4 gives somewhat different results. The growth rate of total government employment per capita is negative and significant. State and local government employment growth is insignificant (equation 
TABLE 4

Intensive Growth Rate Model

Dependent Variable: Growth Rate of Per Capita GSP

\begin{tabular}{|c|c|c|c|c|}
\hline Variable & (1) & (2) & (3) & (4) \\
\hline CONSTANT & $\begin{array}{r}-.036 \\
(.0048)\end{array}$ & $\begin{array}{r}-.040 \\
(.0016)\end{array}$ & $\begin{array}{r}-.039 \\
(.0014)\end{array}$ & $\begin{array}{r}-.034 \\
(.0074)\end{array}$ \\
\hline PCEMPG & $\begin{array}{r}1.372 \\
(.0001)\end{array}$ & $\begin{array}{r}1.375 \\
(.0001)\end{array}$ & $\begin{array}{r}1.379 \\
(.0001)\end{array}$ & $\begin{array}{r}3.510 \\
(.0012)\end{array}$ \\
\hline PCCAPG & $\begin{array}{r}.072 \\
(.0001)\end{array}$ & $\begin{array}{r}.071 \\
(.0001)\end{array}$ & $\begin{array}{r}.071 \\
(.0001)\end{array}$ & $\begin{array}{r}.073 \\
(.0001)\end{array}$ \\
\hline EDUCG & $\begin{array}{r}3.120 \\
(.0001)\end{array}$ & $\begin{array}{r}3.214 \\
(.0001)\end{array}$ & $\begin{array}{r}3.189 \\
(.0001)\end{array}$ & $\begin{array}{r}3.127 \\
(.0001)\end{array}$ \\
\hline PCGOVG & $\begin{array}{r}-.135 \\
(.1277)\end{array}$ & -- & -- & $\begin{array}{r}-2.283 \\
(.0001)\end{array}$ \\
\hline GOVRG & -- & - & - & $\begin{array}{r}2.631 \\
(.0169)\end{array}$ \\
\hline PCSLGG & -- & $\begin{array}{r}.032 \\
(.6895)\end{array}$ & -- & - \\
\hline PFEDG & - & - & $\begin{array}{r}-.078 \\
(.0156)\end{array}$ & - \\
\hline $\operatorname{adj} . R^{2}$ & .761 & .760 & .761 & .764 \\
\hline F & 30.6 & 30.4 & 30.9 & 30.5 \\
\hline
\end{tabular}

Figures in parentheses are significance levels of the t-test. $\mathrm{N}=576$.

(2) while the growth of federal employment is significant, though negative. The results are similar to those in Table 2 when relative government employment is added to the model.

\section{CONCLUSION}

In their paper, Durden and Elledge conclude that their results indicate the existence of a "... positive relationship between GSP and government .... The view that large government is a hindrance to economic growth is not confirmed by our findings ..." (Durden and Elledge, p. 188). The results of this paper suggest that such a conclusion may be appropriate only for an extensive growth 
model. The intensive growth model seems to indicate that a larger government size may hinder the growth of per capita GSP. In addition, evidence presented in Table 3 casts doubt on the existence of a positive effect of government on the growth rate of GSP.

Taken together, the results herein warrant a cautious approach to be taken regarding the relationship between government size and GSP growth. At best, a larger government presence in a state may be able to expand the size of the economic pie, though even that is not certain. However, at worst, a larger government size will decrease the size of the individual slices that people receive.

\section{ENDNOTES}

1. Durden and Elledge use the mean level of education in a state in their study. They estimate equations for 1982 and for the growth of GSP between 1972 and 1982. While it is not explicitly stated in their article, the figures they use for education (as found in the County and City Data Book) must be for 1970 and 1980.

2. Most of the data for this study were obtained from a CD-ROM disk provided by the Bureau of Economic Analysis. The publication date of the disk is May, 1992. Data on capital charges were obtained from Beemiller and Dunbar. Education data were obtained from various issues of the County and City Data Book.

\section{REFERENCES}

Barro, Robert J. "Economic Growth in a Cross Section of Countries." Quarterly Journal of Economics 106 (1991): 407-443.

Beemiller, Richard M., and Ann E. Dunbar. "Gross State Product, 1977-90." Survey of Current Business 73 (1993): 28-49.

Durden, Garey, and Barry Elledge. "The Effect of Government Size on Economic Growth: Evidence from Gross State Product." The Review of Regional Studies 23 (1993): 183-190.

Grossman, Philip J. "Government and Economic Growth: A Non-Linear Relationship." Public Choice. 56 (1988): 193-200.

Landau, Daniel. "Government Expenditures and Economic Growth in the LessDeveloped Countries: An Empirical Study for 1960-1980." Economic Development and Cultural Change 35 (1986): 35-75. 
"Government Expenditure and Economic Growth: A Cross-Country Study." Southern Economic Journal 49 (1983): 783- 92.

Pindyck, Robert S., and Daniel L. Rubinfeld. Econometric Models and Economic Forecasts. New York: McGraw-Hill, Inc., 1991.

Ram, Rati. "Government Size and Economic Growth: A New Framework and Some Evidence from Cross-Section and Time series Data." American Economic Review. 76 (1986). 191-203.

Bureau of Economic Analysis, U.S. Department of Commerce. Regional Economic Information System, 1969-1990.

U.S. Bureau of the Census. County and City Data Books, 1972, 1982, 1992. Washington, D.C.: U.S. Government Printing Office, 1973, 1983, 1993. 


$$
\text { - }
$$

